\title{
Anarchism, Religion, and the Religiousness of Political Ideologies
}

\author{
Alexandre Christoyannopoulos \& Matthew S. Adams \\ Loughborough University, UK
}

Borders are often messy, contested spaces. This is true not just of physical borders, but intellectual ones too: the spaces between traditions, ideas, and concepts are often disputed territories. The border between 'religion' and 'political ideology' is no different. At first sight, the central focus of each seems different: religions appear to deal with the divine, whereas political ideologies are ostensibly concerned with the all-too-human world of political and economic reality. But on closer inspection this confident distinction appears more vulnerable: both terms signify systems of thought and associated practices; religions do not always refer to God or gods (and the assumption that religions deal with the divine is narrow, rather monotheistic, and quite Eurocentric); nearly all religions take positions on political and economic questions; and political ideologies can be preached with religious fervour, can elevate particular people to the status of 'prophets', and often come with their own revered symbols and memorabilia. At a minimum, therefore, we might say that 'religion' and 'political ideology' are locked in a territorial dispute, their shared boundary vulnerable to marauding bands from either side.

Definitions do not help tidy up the distinction. We noted how diverse the definitions of 'religion' are in our introduction to Volume II. ${ }^{\mathrm{I}}$ But there is no single definition of 'ideology' either, with

We are very grateful to the two anonymous reviewers' suggestions to improve this introduction, many of which we have taken on board.

${ }^{I}$ Alexandre Christoyannopoulos and Matthew S. Adams, "Anarchism and Religion: Exploring Definitions," in Essays in Anarchism and Religion:

How to cite this book chapter:

Christoyannopoulos, A. and Adams, M. S. 2020. Anarchism, Religion, and the Religiousness of Political Ideologies. In: Christoyannopoulos, A. and Adams, M. S. (eds.) Essays in Anarchism and Religion: Volume III. Pp. I-20. Stockholm: Stockholm University Press. DOI: https://doi.org/Io.I6993/ bbb.a. License: CC-BY. 
millions of politics students being offered at least four different standard stories from which to choose: for many Marxists, ideology refers to a distortion of reality, a false narrative which is controlled by the ruling classes and which distracts the exploited from recognising the fact of their exploitation; for many liberals, ideology denotes a closed (even totalitarian) system of thought which provides a means of ensuring compliance; for conservatives, ideologies are dangerous simplifications of an unavoidably complex reality, which lead to ill-conceived policies; and for many social scientists, the term describes something more analytical than polemical, a framework of thought which explains current conditions, envisions a set of alternatives, and proposes a particular route to get there. ${ }^{2}$ Where ideology was once the provenance of the narrowly political - that is, it was the subject of critique from expressly political (we might say, ideological) positions and interpreted essentially as a means to advance special interests this diverse field now focuses more squarely on the internal logic of ideological systems of thought, how ideologies emerge in particular historical contexts as reflections of intellectual and practical developments, and how they adapt with time to remain useful in changing historical circumstances. ${ }^{3}$

Yet religion provides examples of every one of these meanings of 'ideology': deluded and distracting distortions of reality; closed systems of thought that facilitate compliance; simplifications of reality which lead to ill-advised choices; or indeed narratives of the current order, visions of alternative futures, and preferred paths to their realisation. Religions can, therefore, sometimes be

Volume II, ed. Alexandre Christoyannopoulos and Matthew S. Adams, Stockholm Studies in Comparative Religion (Stockholm: Stockholm University Press, 20I 8).

2 Andrew Heywood, Political Ideologies: An Introduction, 6th ed. (London: Palgrave, 2017); Andrew Vincent, Modern Political Ideologies, 2nd ed. (Oxford: Blackwell, I995).

3 The literature here is vast, but the most famous and important representative is Michael Freeden, Ideologies and Political Theory: A Conceptual Approach (Oxford: Clarendon, 2008). For an application of Freeden's technique to anarchism, consider: Benjamin Franks, Nathan Jun, and Leonard Williams, eds., Anarchism: A Conceptual Approach (Abingdon: Routledge, 20I8). 
labelled 'ideological'. But it also works the other way round too: political ideologies such as socialism or feminism or fascism can be 'religious' in the sociological sense of the word, providing communities with unified systems of beliefs and practices, for example, or, in the anthropological sense, providing a system of symbols that help make sense of the world and motivate action within it.

In short: the terms 'religion' and 'ideology' are difficult to decisively separate and then keep apart. In the collection of essays of which this is the third volume, we are interested in one specific political ideology: anarchism. The limited ambition of this introduction, therefore, building on the discussions of anarchism and religion in the introductions to the previous two volumes, is to ponder the extent to which anarchism can be considered 'religious' or be said to display 'religious' characteristics. ${ }^{4}$

\section{Anarchism as 'religion'?}

The definition of 'religion' is contested. To repeat our comments in Volume II:

some employ the term broadly to include all the spiritualities and practices which can be considered 'religious', whereas others insist on the label applying more narrowly to more institutionalised and often Western-centric practices and beliefs, and do so precisely in order to differentiate such examples of religiosity from nonWestern and less institutionalised spiritualities and rituals. ${ }^{5}$ Some definitions hinge on the object of worship (God or gods), others on ritual practices, others still on the state of mind which opens itself to it. ${ }^{6}$ Some insist on religion being a private matter, sometimes

4 Alexandre Christoyannopoulos and Matthew S. Adams, "Anarchism and Religion: Mapping an Increasingly Fruitful Landscape," in Essays in Anarchism and Religion: Volume I, ed. Alexandre Christoyannopoulos and Matthew S. Adams, Stockholm Studies in Comparative Religion (Stockholm: Stockholm University Press, 20I7); "Anarchism and Religion.”

"Paul Heelas and Linda Woodhead, The Spiritual Revolution: Why Religion Is Giving Way to Spirituality (Oxford: Blackwell, 2005); Philip Sheldrake, Spirituality: A Brief History (Oxford: John Wiley and Sons, 2013).

6 John Bowker, "Religion," in The Concise Oxford Dictionary of World Religions ed. John Bowker (Oxford: Oxford University Press, 2000), pp. xviii-xiv; John Hinnells, ed. The Penguin Dictionary of Religions, 
with an explicit determination to keep it independent from politics. ${ }^{7}$ Others argue that religion cannot but inevitably be political, and that its confinement to the 'private' sphere is actually the result of a political project. ${ }^{8}$ Then there is the category of 'civil religion' to describe politics than looks like 'religion'. ${ }^{9}$

In the discussion that followed, we also acknowledged some of the cultural biases which predispose people towards different kinds of definition of 'religion', emphasising, for example, beliefs, or ritual practices, or moral guidelines. And we noted that

2nd ed. (London: Penguin, I995), pp. 4I4-16; Moojan Momen, The Phenomenon of Religion: A Thematic Approach (Oxford: Oneworld, I999), pp. 26-28, and chap. 3 .

7 Jean Baubérot and Micheline Milo, Laïcités Sans Frontières (Paris: Seuil, 20I I); Ahmet T. Kuru, Secularism and State Policies toward Religion: The United States, France, and Turkey (Cambridge: Cambridge University Press, 2009); Erica Michelle Lagalisse, “'Marginalizing Magdalena': Intersections of Gender and the Secular in Anarchoindigenist Solidarity Activism," Signs: Journal of Women in Culture and Society 36, no. 3 (20II); Tariq Modood, "Moderate Secularism, Religion as Identity, and Respect for Religion," The Political Quarterly 8I, no. I (2010); Graeme Smith, A Short History of Secularism (London: I.B.Tauris, 2008).

${ }^{8}$ Steve Bruce, Politics and Religion (Cambridge: Polity, 2003); José Casanova, Public Religions in the Modern World (Chicago: University of Chicago Press, I994); William T. Cavanaugh, "A Fire Strong Enough to Consume the House: The Wars of Religion and the Rise of the State," Modern Theology I I, no. 4 (I995); Alexandre Christoyannopoulos and Anthony T. Fiscella, "'Religious' Radicalism," in Routledge Handbook of Radical Politics, ed. Uri Gordon and Ruth Kinna (London: Routledge, 2019); Jonathan Fox, An Introduction to Religion and Politics: Theory and Practice (Oxon: Routledge, 2013); Jeffrey Haynes, ed. Routledge Handbook of Religion and Politics (London: Routledge, 2009); Nikki R. Keddie, "Secularism and Its Discontents," Dodalus I32, no. 3 (2003); Steven Kettell, “Do We Need a 'Political Science of Religion'?,” Political Studies Review I4, no. 2 (2016); Pippa Norris and Ronald Inglehart, Sacred and Secular: Religion and Politics Worldwide (Cambridge: Cambridge University Press, 20I I).

9 Robert N. Bellah and Phillip E. Hammond, Varieties of Civil Religion (Eugene, OR: Wipf and Stock, I980); John A. Coleman, "Civil Religion," Sociology of Religion 3 I, no. 2 ( I 970); Emilio Gentile, Politics as Religion, trans. George Staunton (Princeton: Princeton University Press, 200I); John Markoff and Daniel Regan, "The Rise and Fall of Civil Religion: Comparative Perspectives," Sociological Analysis 42, no. 4 (I98I). 
scholarly definitions also tend to reflect the academic discipline, and therefore common disciplinary assumptions, of their authors.

'Anarchism' is not, of course, an ideological practice managed by an organisation that resembles mainstream Christian churches. The object of worship is not a god, nor is anarchism, for most anarchists, a state of mind open to the divine. Indeed many anarchists have been firm critics of religion (especially Christianity), just as there are many determined religious critics of anarchism. ${ }^{\circ}$ Anarchism is also not a private matter. Nor does it gel a whole polity's civil society (at least not yet). Besides, the term itself is contested, and there are many varieties of 'anarchism' that make it, superficially at least, resistant to easy assimilation. It would be misleading therefore to claim that 'anarchism' can be straightforwardly classified as a 'religion'.

Nonetheless, 'anarchism' does display the characteristics of 'religion', especially once we appreciate that Christianity, even with its many variants, is only one particular kind of religion. As we noted in Volume II, Ninian Smart identifies the following

characteristics [...] found in all 'religion': practical and ritual (the religious performances and celebrations that punctuate days,

to A sample of anarchist criticisms of religion (mainly Christianity) is presented in Alexandre Christoyannopoulos and Lara Apps, "Anarchism and Religion," in The Palgrave Handbook of Anarchism, ed. Carl Levy and Matthew S. Adams (Basingstoke: Palgrave Macmillan, 20I9); "Anarchism and Religion," in Brill's Companion to Anarchism and Philosophy, ed. Nathan Jun (Leiden: Brill, 2018). Another example is Aaron S. Tamaret, Ha-Emuna Ha-Tehora Ve-Ha-Dat Ha-Hamonit (Odessa: Halperin, I9 2). Examples of religious (Christian and Jewish) criticisms of anarchism include: Thomas Campbell, "Anarchy," The Catholic Encyclopedia (New York: Robert Appleton, I907), http:// www.newadvent.org/cathen/oI452a.htm; Abraham I. Kook, Igrot HaRaya, vol. I (Jerusalem: Mosad ha-Rav Kook, I962), I74-75, 229-30; Reinhold Niebuhr, "Catholicism and Anarchism in Spain," Radical Religion 2, no. 2 (I937). If one however broadens the search to religious scholars and theologians who criticise 'lawlessness', political 'anarchy' and the like, and who advocate political order, hierarchies and state-like formations - in other words if one looks beyond religious criticisms focused specifically on anarchist theories and practices - then the religious literature critical of 'anarchism' is vast. 
months and years); experiential and emotional (Paul's or Buddha's conversions, religious music and art, etc.); narrative or mythic (the story of our origins); doctrinal and philosophical (theology, dogma, metaphysics, etc.); ethical and legal (how we are to live our lives); social and institutional (the community of adherents and its social function); and material (the physical buildings and sacred places). ${ }^{\text {II }}$

Again, however, looking at anarchism with such characteristics in mind illustrates the permeability of any border wall between anarchism and religion.

The doctrinal and philosophical dimension of anarchism, for example, encompasses a variety of trends, but anarchists do unite in denouncing structures of oppression and injustice, especially the state. Most of them are just as united and passionate in their denunciation of capitalism, racism, sexism and other coercive inequalities too. Most are atheists or at least anticlerical. Although there is of course lively debate on a number of topics (violence, diet, religion, etc.), there is therefore a 'doctrinal and philosophical' core to anarchism, subscription to which is treated as a prerequisite for the legitimate application of the label. Moreover, internal debates often involve references to core, 'doctrinal' or defining anarchist values. As for the underlying 'philosophical' and metaphysical grounding of these values, even though anarchism has a tendency to heterodoxy that accommodates a diversity of angles ('classical' and rationalistic, post-structuralist, or indeed even religious), and even though there can be vehement debate between proponents of each, there is a broad understanding about which trends are authorised under the label (classical and post-structuralist, for example) and which are not, with religious ones often treated with considerable suspicion, and 'anarcho-capitalists' with firm disdain. Either way, even allowing for some diversity, there is a 'doctrinal and philosophical' core to anarchism.

This anarchist 'doctrine' also includes a narrative or mythic dimension, with a particular origin story. At one level, for most, this involves a materialistic and scientific understanding of the origins

II Ninan Smart, The World's Religions, Second ed. (Cambridge: Cambridge University Press, I998), pp. I2-22. 
of life, though here again religious anarchists provide notable exceptions - which is not to say they all reject science altogether. Anarchists also tend to offer a shared historical narrative: that is, all offer some variant of the spread of capitalist exploitation working in parallel or tandem with the rise of the nation state. The contours of this story are often shaped by an individuals' stance regarding other important themes, say the role of colonialism, gender inequalities, or racism. That narrative then helps explain the current human predicament, identifies historic transformations and heroic moments, and provides a collective memory for the movement. The writing of anarchist intellectual histories is a component of this identity-building. For a thinker like Kropotkin, historical example was a useful tool in demonstrating the practicability of anarchist ideas in the face of scepticism, but a particular history of anarchism - tracing its emergence as an intellectual force that reflected the broader development of social scientific thinking - also underpinned his own political identity. As with all narratives this was a constructed one (that is not to say it is necessarily false), but it was integral in burnishing a distinctively anarchist identity weighted with intellectual pedigree. ${ }^{\mathrm{I2}}$

Anarchism might not generate institutions in the typical sense of top-down hierarchies like the state or the private corporation, but there is an important social and institutional dimension nonetheless. For one, the list of 'institutions' founded and run by anarchists is considerable, and includes, among others, syndicalist organisations, housing communes, producer cooperatives, solidarity networks, and publishing collectives. These 'institutions' all provide essential social functions for anarchist communities: to meet, assist, debate, learn and of course organise and resist. What does tend to mark out these anarchist organisations from typical 'institutions' is their anarchist organisational ethos: radically participative, inclusive, bottom-up and renegotiable. Yet they are, nonetheless, 'institutions'.

${ }^{12}$ Matthew S. Adams, Kropotkin, Read, and the Intellectual History of British Anarchism: Between Reason and Romanticism (Basingstoke: Palgrave Macmillan, 20I 5), 77-88. 
If legal is a problematic term to apply to anarchists, ethical is not. All variants of anarchism preach particular ways of living our lives, or rather at least recommend some over others. Indeed, prefiguration - i.e. trying to embody in one's conduct the principles that one preaches - is an important consideration for most anarchists. Moreover, certain kinds of behaviour are considered unacceptable in anarchist settings, as evidenced for instance in the articulation of safe space policies. Besides, even if 'legal' is a term which problematically evokes the state, many anarchist organisations do write down collectively-agreed rules, adherence to which is expected for continued participation, and constitutionalising has always been, despite the usual assumptions about anarchism, a key anarchist practice. ${ }^{13}$ There is therefore an 'ethical and legal' dimension to anarchism.

One cannot point, of course, to 'religious' performances and celebrations among anarchists in the (narrow and Eurocentric) sense of regular worship of the divine. Yet a practical and ritual element can still be identified. The prefigurative performance of one's principles acts as a confirmation of one's commitment, not least during formal meetings. Particular historical moments are also often celebrated: the International Workers' Day is an important date on the calendar; and anarchists have actively commemorated specific events, such as the Paris Commune, or the anarchist revolution in Catalonia during the Spanish Civil War. The holiday - May Day in particular - is sacred and must be protected from encroaching neoliberal demons. Rallies and demonstrations - both generally and those marking particular historical events - are sites of anarchist performance. In a similar manner, the anarchist clandestine cell and secret society that were ubiquitous in nineteenth-century sensational fiction reflected the value of ritual in the context of official oppression. We might say, therefore, drawing on Benedict Anderson's phrase, that anarchism was something of an 'imagined community', its symbols and practices offering the comforting rituals of fellow-feeling

${ }^{13}$ April Carter, The Political Theory of Anarchism (London: Harper Torchbooks, I97I), 56-59; Ruth Kinna and Alex Prichard, "Anarchism and Non-Domination," Journal of Political Ideologies 24, no. 3 (2019). 
and recognition in times of political stress. ${ }^{\mathrm{I}}$ In short, various performances and celebrations punctuate anarchist timelines and thus provide anarchism with a practical and ritual dimension.

The material facet is there too: social centres, squats, bookshops, soup-kitchens and suchlike happen in specific locations, sometimes in the face of de facto and de jure persecution. Sometimes, such as, for example, with the immigrant anarchist communities in New York at the end of the nineteenth century, the ritual gathering in the beer hall or meeting room became practically and emotionally foundational for the local anarchist scene. ${ }^{\text {Is }}$ Over time, some of these anarchist spaces become revered and can even become sites of pilgrimage. Anarchists might not gather in churches and treat sites like the Temple Mount as holy therefore, but an anarchist geography does nonetheless map buildings and places, ascribe higher status to some sites over others, and inform anarchist commemorations. Also notable are the material sites of 'evil' such as the prison, the border, the royal or presidential palace, the shopping mall and so on.

There is also an experiential and emotional dimension to anarchism. Not unlike Paul or Buddha, some famous anarchists did 'convert' after particular tribulations. Experiences of injustice are keenly felt, as are experience of empowerment. Indeed, demonstrations can conjure up powerful emotions. And many examples could be listed of anarchist art and music, including revolutionary anthems, protest banners, street art, punk music and aesthetics, ${ }^{16}$ or even the instantly-recognisable A-in-an-O symbol that can illicit emotional responses and inform the group-feeling.

In short: anarchism displays many of the same characteristics as religion that Smart identifies. There may not be gods in the

${ }^{14}$ Adams, Kropotkin, Read, and the Intellectual History of British Anarchism, I82-87.

is Consider the chapters by Tom Goyens, Kenyon Zimmer, Marcella Bencivenni and Christopher J. Castañeda in Tom Goyens, ed. Radical Gotham: Anarchism in New York City from Schwab's Saloon to Occupy Wall Street (Urbana: University of Illinois Press, 20I7).

${ }^{16}$ Jim Donaghey, "Punk and Anarchism: Uk, Poland, Indonesia" (Loughborough University, 20I6); Francis Stewart, Punk Rock Is My Religion: Straight Edge Punk and 'Religious' Identity (Abingdon: Routledge, 2017). 
traditional sense (except of course for religious anarchists), and anarchists may be more iconoclastic than other political traditions, yet particular heroic comrades are celebrated, nonetheless. And even though they are rarely anthropomorphised, principles such as freedom, equality or non-domination can be, in a sense, 'worshipped'. Just as religions do, anarchism presents its adherents with a historical narrative, a doctrinal core, various institutionalised settings, a set of ethical expectations, concrete material spaces, particular rituals, and strong emotions.

There are other ways of making a similar argument. For example, the literature on 'civil' or 'political' religion precisely argues that certain political ideologies and practices resemble 'religious' equivalents and indeed perform functions historically performed by religion (especially mainstream Christianity). ${ }^{17}$ Fairly obvious examples (because of their totalising tendencies) include some types of nationalism, fascism, and state communism, but other ideologies also arguably display at least some characteristics of 'civil religion'. In the case of anarchism, to echo some of what has already been evoked above, these characteristics of 'civil religion' might include: an awareness of the sacrifices required for the cause, and a willingness to make them (almost as a public duty); respectful commemoration of courageous martyrs; collective rituals and performances punctuating anarchist calendars; the cultivation of particular spaces for important gatherings and other activities; use of symbols to signal belonging as well as to proselytise; and a strong sense of community, comradeship and belonging. At the same time, no variant of anarchism has yet held together, as the dominant ideology, a coherent and sovereign body politic resembling a state (Republican Spain was ideologically diverse and unstable, Makhnovist Ukraine did not survive its founding guerrilla war, and Rojava's ideology blends what anarchism informs it with obvious ethno-nationalist undercurrents). Nor does anarchism impose itself and punish deviance in the way more classic 'civil religions' have, although it can certainly imply expectations, and perhaps even assume that civical-

7 Bellah and Hammond, Varieties of Civil Religion; Coleman, "Civil Religion."; Gentile, Politics as Religion; Markoff and Regan, "The Rise and Fall of Civil Religion: Comparative Perspectives." 
ly-minded anarchists would perform particular duties. ${ }^{18}$ There is also no biblical imagery, nor any evocation of theological vocabulary (except in religious anarchism). The extent to which the label of 'civil religion' applies to anarchism is therefore disputable, even if some characteristics are nevertheless present.

Yet another alternative framework from the sociology of religion that could be used to illustrate the ways in which anarchism is akin to religion comes from the literature on 'implicit religion', according to which religion consists in 'commitment(s)', 'integrating foci', and 'intensive concerns with extensive effects'. ${ }^{19}$ It is not difficult to contemplate ways in which anarchism meets such defining criteria: anarchism grows from sincere commitment (both conscious and subconscious); it provides a content around which adherents find common purpose and integrate into groups (small to large scale); and it articulates intensive concerns which its adherents feel and express across the various sites of their existence. Anarchism, or some instances of it anyway, could possibly therefore be considered an 'implicit religion'. Similar explorations could be articulated using Tillich's description of religion as 'ultimate concern' or Luckmann's notion of 'invisible religion'. Either way, the argument remains that in more ways than one, anarchism (just like many other political ideologies) displays characteristics of 'religion'.

It might also be helpful here to briefly recall the expanding scholarship that has questioned the very assumption that the 'secular' can be distinguished from the 'religious'. Talal Asad's genealogical critique of these categories for example justifies caution when affirming rigid distinctions between the two, especially given how these categories are rooted in violent imperialist projects. ${ }^{20}$ The

${ }^{18}$ Matthew S. Adams, "Utopian Civic Virtue: Bakunin, Kropotkin, and Anarchism's Republican Inheritance", Political Research Exchange (2019), I-27.

19 Edward Bailey, Implicit Religion: An Introduction (London: Middlesex University Press, I998); “Implicit Religion,” ed. Peter B. Clarke, The Oxford Handbook of the Sociology of Religion (Oxford University Press, 20II), https://www.oxfordhandbooks.com/view/I0.I093/oxfordhb/9780I9958896I.00I.000I/oxfordhb-9780I9958896I-e-045; Stewart, Punk Rock Is My Religion.

${ }_{20}$ Talal Asad, Formations of the Secular: Christianity, Islam, Modernity (Stanford: Stanford University Press, 2003); Genealogies of Religion: 
process of 'secularisation' has in part been a vehicle with which the modern Westphalian state established its sovereign power by subjugating 'religious' competitors. ${ }^{21}$ It is also interesting that political ideologies as a phenomenon only emerge as this modern Westphalian state affirms itself, in a sense filling a vacuum or performing various functions previously covered by 'religion'. Perhaps, then, common to both 'religion' and 'political ideologies' (including anarchism) are a range of existential and social concerns, social functions, and moral, ritual and emotional drives that can be observed in all human societies (ostensibly 'religious' or not). And perhaps all observers need to remain alert to the political interests that can be served by the labelling of social phenomena as 'religion', 'anarchism' or 'ideology'.

What, then, does a depiction of anarchism as akin to religion achieve? Our intention is not to flatten out all differences: even if anarchism displays characteristics one finds in 'religion', 'political ideology' probably remains a more apposite term to label this system of thought and its associated practices, at least in the sense that it is less likely to generate sometimes unhelpful confusion. What we do hope to have shown, though, is that what is distinct about 'religion' is not easily defined and captured; that the characteristics of religion (especially when looking beyond conventional Christianity) are similar to those of the beliefs and practices of an ideology such as anarchism; and that caution and nuance are therefore desirable when categorising phenomena as 'ideological' or 'religious'.

Either way, dismissing beliefs and practices simply because they are classed as either 'religious' or 'ideological' is both lazy and simplistic. Far more interesting and rewarding is engaging with their content. And indeed, such effort usually leads to inevitable nuancing and deeper reflection. With this collection of essays on anarchism and religion (including Volumes I and II), we hope to have demonstrated the merits of closer engagement with the very

Discipline and Reasons of Power in Christianity and Islam (Baltimore: Johns Hopkins University Press, I993). See also Christoyannopoulos and Fiscella, “'Religious' Radicalism.”

21 Cavanaugh, "A Fire Strong Enough to Consume the House."; Christoyannopoulos and Fiscella, “'Religious’ Radicalism.” 
diverse lines of argument and analyses that can be articulated about anarchism, religion, and their interaction. A closer reading of the various authors and themes covered in these volumes demonstrates that 'anarchism' and 'religion' are not as inevitably mutually exclusive as can at first seem. That anarchism (just as other political ideologies) can be interpreted as in some ways akin to religion further justifies the nuancing of intellectual boundaries.

\section{The essays in this volume}

Taken together, the three volumes of our project include most of the original contributions to the 2012 Anarchist Studies Network conference at Loughborough University, where this project first emerged, as well as several further essays that have been added to the project. We hope that this will not be the last volume of the sort, the first three having illustrated the vibrancy and multi-faceted nature the discussions around anarchism and religion.

The above conceptual and theoretical discussion does not concern exclusively the essays in this volume, nor are they essential to approach the content of these essays - they rather speak to the broader topic of 'anarchism and religion' which englobes all three volumes. Moreover, the selection of essays in this particular volume, just as in the previous two, is the accidental product of circumstance: the essays that have been part of the project since $20 \mathrm{I} 2$ came to be ready for publication roughly in the order in which they appear across the three volumes. Nevertheless, there is in this third volume some degree of informal narrative continuity, with most chapters introducing a theme that is in some way taken up by the next. The last two chapters also do happen to speak more directly to the conceptual discussion above. ${ }^{22}$

In this present volume, five essays focus on a particular individual (Heyn, Tolstoy, Read, Guérin and Buber) and thus offer case studies of authors standing with one foot in anarchism

${ }_{22}$ We are particularly grateful to an anonymous reviewer for encouraging us to clarify these points. 
and the other (to some degree at least) in religion. One essay focuses on the affinities between mysticism and anarchism, and a final one on the vast territory covered by the label 'spiritual anarchism'. As has been the case with the broader project emanating from the $20 \mathrm{I} 2$ conference, Christianity is heavily represented here, as are Western white males. We hope to redress these imbalances in a potential fourth volume focused exclusively on interrogating these issues. Rectifying centuries-old biases is a challenging task for a small team working on already heavilybiased material, but we remain open to considering projects that aim to redress this. Meanwhile, this third volume is once again dominated by white Christianity.

Non-Christian perspectives nevertheless feature in two essays in this volume. In the first chapter, Hayyim Rothman inscribes Abraham Heyn's anti-authoritarian, anti-militarist and universal ethos into the Jewish tradition. He does this by outlining three themes in Heyn's Jewish anarcho-pacifism: the notion that the essence of Judaism consists in a conviction of the absolute sanctity of human life; the implication for an anarcho-pacifist vision of society; and the prefigurative revolutionary method that follows, with its emphasis on moral transformation. This therefore provides a second essay on Jewish voices within the three volumes to date.

Pacifism figures too in the second chapter, as Alexandre Christoyannopoulos presents a condensed version of his recently published monograph on Leo Tolstoy's political thought. ${ }^{23}$ The chapter examines Tolstoy's pacifism, anarchism, anticlericalism and activism, each time considering Tolstoy's main claims first, then some of the criticisms of his views, and then assessing the ongoing relevance of these arguments.

Where Tolstoy is unproblematically described as a religious anarchist, Matthew S. Adams' chapter explores a thinker who would have rejected this label: the art critic and anarchist intellectual Herbert Read. Nevertheless, Adams argues that consi-

${ }^{23}$ Alexandre Christoyannopoulos, Tolstoy's Political Thought: Christian Anarcho-Pacifist Iconoclasm Then and Now, Routledge Series on Russian and East European Studies (Abingdon: Routledge, 2020). 
dering Read's theoretical edifice in relation to the spiritual can be illuminating. Developed through a comparison with the work of H.G. Wells, Adams shows how Read saw some sort of spiritual union as a crucial part of a successful society, and that this spiritual dimension would inform an artistic flourishing, Read's measure of the successful diffusion of freedom.

The relevance of thinking about anarchism's relation to conceptions of spiritual union is explored further in the fourth chapter. Daniel Guérin's contribution to anarchism is well established, but less well-known is the extent to which his political commitments might have been sometimes motivated by religious or spiritual ideas. In the fourth chapter, David Berry examines precisely these influences, and in particular considers Guérin's discovery of Tolstoy, his friendship with novelist François Mauriac, and his struggle with the reactionary stance of the Catholic church. Berry also reflects on the role, for Guérin, of redemption through a Gandhian form of love or fraternity, seeing this as a kind of secular religion.

Where Read and Guérin are both thinkers not typically viewed in terms of the religious and spiritual, Martin Buber, like Tolstoy, wore these influences proudly. In chapter five, Sarah Scott reconstructs Buber's conception of grace to show its importance for unifying his religious orientation and anarchist tendencies. She explains that previous accounts of Buber's notion of grace were incomplete, because he reinterprets Augustinian grace as not just from God but also from our relations with other creatures. This paves the way for an anarchist politics by side-stepping Augustine's dependence on hierarchy and submission.

Departing from the study of individual thinkers, in the sixth chapter, Stefan Rossbach considers affinities between mysticism (in theology) and anarchism (in political theory). Drawing from Plato, Rousseau and Landauer, he argues that both mysticism and anarchism involve a 'stepping out' from the mainstream and a rejection of what he calls 'externalising practices'.

The final chapter opens the discussion to a far wider range of 'religious' and 'spiritual' perspectives. More specifically, Anthony Fiscella critically examines how and when 'spiritual anarchism' has been applied as a label, and how it could be applied. In 
the process, he provides an extensive overview of both existing literature and forgotten stories, and comments on the colonial legacies than tend to afflict scholarly work on the topic.

As with Volumes I and II, we believe that this volume presents a striking variety of angles on anarchism and religion that points to both the health of the emerging field, and the deep complexities that characterise considerations of both the religious and anarchist political thought. We hope that readers will agree, and find these essays stimulating and challenging.

Alexandre Christoyannopoulos and

Matthew S. Adams, January 2020

\section{References}

Adams, Matthew S. "Utopian Civic Virtue: Bakunin, Kropotkin, and anarchism's republican inheritance", Political Research Exchange (20I9), I-27.

- Kropotkin, Read, and the Intellectual History of British Anarchism: Between Reason and Romanticism. Basingstoke: Palgrave Macmillan, 20I 5.

Asad, Talal. Formations of the Secular: Christianity, Islam, Modernity. Stanford: Stanford University Press, 2003.

- Genealogies of Religion: Discipline and Reasons of Power in Christianity and Islam. Baltimore: Johns Hopkins University Press, I993.

Bailey, Edward. "Implicit Religion." In The Oxford Handbook of the Sociology of Religion, edited by Peter B. ClarkeOxford University Press, 20II. https://www.oxfordhandbooks.com/view/ I 0.1093/oxfordhb/9780I 9958896 I.00I.000I/oxfordhb9780I9958896I-e-045.

- Implicit Religion: An Introduction. London: Middlesex University Press, I998.

Baubérot, Jean, and Micheline Milo. Laïcités Sans Frontières. Paris: Seuil, 20I I.

Bellah, Robert N., and Phillip E. Hammond. Varieties of Civil Religion. Eugene, OR: Wipf and Stock, I980. 
Bowker, John. "Religion." In The Concise Oxford Dictionary of World Religions edited by John Bowker. Oxford: Oxford University Press, 2000.

Bruce, Steve. Politics and Religion. Cambridge: Polity, 2003.

Campbell, Thomas. "Anarchy." In The Catholic Encyclopedia New York: Robert Appleton, 1907. http://www.newadvent.org/ cathen/or 452a.htm.

Carter, April. The Political Theory of Anarchism. London: Harper Torchbooks, I97I.

Casanova, José. Public Religions in the Modern World. Chicago: University of Chicago Press, I994.

Cavanaugh, William T. "A Fire Strong Enough to Consume the House: The Wars of Religion and the Rise of the State." Modern Theology I I, no. 4 (October I995): 397-420.

Christoyannopoulos, Alexandre. Tolstoy's Political Thought: Christian Anarcho-Pacifist Iconoclasm Then and Now. Routledge Series on Russian and East European Studies. Abingdon: Routledge, 2020.

Christoyannopoulos, Alexandre, and Matthew S. Adams. "Anarchism and Religion: Exploring Definitions." In Essays in Anarchism and Religion: Volume II, edited by Alexandre Christoyannopoulos and Matthew S. Adams. Stockholm Studies in Comparative Religion, I-I9. Stockholm: Stockholm University Press, 20 I 8.

—_, "Anarchism and Religion: Mapping an Increasingly Fruitful Landscape." In Essays in Anarchism and Religion: Volume I, edited by Alexandre Christoyannopoulos and Matthew S. Adams. Stockholm Studies in Comparative Religion, I-I7. Stockholm: Stockholm University Press, 2017.

Christoyannopoulos, Alexandre, and Lara Apps. "Anarchism and Religion." Chap. 9 In The Palgrave Handbook of Anarchism, edited by Carl Levy and Matthew S. Adams, I69-92. Basingstoke: Palgrave Macmillan, 20I9.

—_, "Anarchism and Religion." In Brill's Companion to Anarchism and Philosophy, edited by Nathan Jun, I20-5I. Leiden: Brill, 20 I 8. 
Christoyannopoulos, Alexandre, and Anthony T. Fiscella. “'Religious' Radicalism.” In Routledge Handbook of Radical Politics, edited by Uri Gordon and Ruth Kinna, I-I7. London: Routledge, 2019.

Coleman, John A. “Civil Religion.” Sociology of Religion 3 I, no. 2 (July I970): 67-77.

Donaghey, Jim. "Punk and Anarchism: Uk, Poland, Indonesia." Loughborough University, 2016.

Fox, Jonathan. An Introduction to Religion and Politics: Theory and Practice. Oxon: Routledge, 2013.

Franks, Benjamin, Nathan Jun, and Leonard Williams, eds. Anarchism: A Conceptual Approach. Abingdon: Routledge, 2018.

Freeden, Michael. Ideologies and Political Theory: A Conceptual Approach. Oxford: Clarendon, 2008.

Gentile, Emilio. Politics as Religion. Translated by George Staunton. Princeton: Princeton University Press, 200I.

Goyens, Tom, ed. Radical Gotham: Anarchism in New York City from Schwab's Saloon to Occupy Wall Street. Urbana: University of Illinois Press, 2017.

Haynes, Jeffrey, ed. Routledge Handbook of Religion and Politics. London: Routledge, 2009.

Heelas, Paul, and Linda Woodhead. The Spiritual Revolution: Why Religion Is Giving Way to Spirituality. Oxford: Blackwell, 2005.

Heywood, Andrew. Political Ideologies: An Introduction. 6th ed. London: Palgrave, 2017.

Hinnells, John, ed. The Penguin Dictionary of Religions. 2nd ed. London: Penguin, I995.

Keddie, Nikki R. "Secularism and Its Discontents." Doedalus I32, no. 3 (2003): I $4-30$.

Kettell, Steven. "Do We Need a 'Political Science of Religion'?". Political Studies Review I4, no. 2 (2016): 210-22.

Kinna, Ruth, and Alex Prichard. "Anarchism and Non-Domination." Journal of Political Ideologies 24, no. 3 (2019): 22 I-40.

Kook, Abraham I. Igrot Ha-Raya. Vol. I, Jerusalem: Mosad ha-Rav Kook, I962. 
Kuru, Ahmet T. Secularism and State Policies toward Religion: The United States, France, and Turkey. Cambridge: Cambridge University Press, 2009.

Lagalisse, Erica Michelle. “"Marginalizing Magdalena”: Intersections of Gender and the Secular in Anarchoindigenist Solidarity Activism." Signs: Journal of Women in Culture and Society 36, no. 3 (Spring 20II): 653-78.

Markoff, John, and Daniel Regan. "The Rise and Fall of Civil Religion: Comparative Perspectives.” Sociological Analysis 42, no. 4 (I98 I): 333-52.

Modood, Tariq. "Moderate Secularism, Religion as Identity, and Respect for Religion." The Political Quarterly 8I, no. I (2010): 4-I4.

Momen, Moojan. The Phenomenon of Religion: A Thematic Approach. Oxford: Oneworld, I999.

Niebuhr, Reinhold. "Catholicism and Anarchism in Spain." Radical Religion 2, no. 2 (Spring I937): 25-28.

Norris, Pippa, and Ronald Inglehart. Sacred and Secular: Religion and Politics Worldwide. Cambridge: Cambridge University Press, 20 I I.

Sheldrake, Philip. Spirituality: A Brief History. Oxford: John Wiley and Sons, 2013.

Smart, Ninan. The World's Religions. Second ed. Cambridge: Cambridge University Press, I998.

Smith, Graeme. A Short History of Secularism. London: I.B. Tauris, 2008.

Stewart, Francis. Punk Rock Is My Religion: Straight Edge Punk and 'Religious' Identity. Abingdon: Routledge, 2017.

Tamaret, Aaron S. Ha-Emuna Ha-Tehora Ve-Ha-Dat Ha-Hamonit. Odessa: Halperin, I9I 2.

Vincent, Andrew. Modern Political Ideologies. 2nd ed. Oxford: Blackwell, I995. 